\title{
Corruption and Infrastructure at the Country and Regional Level
}

\author{
Robert Gillanders \\ Aalto University and HECER
}

Discussion Paper No. 365

April 2013

ISSN 1795-0562

HECER - Helsinki Center of Economic Research, P.O. Box 17 (Arkadiankatu 7), FI-00014 University of Helsinki, FINLAND, Tel +358-9-191-28780, Fax +358-9-191-28781, E-mail info-hecer@helsinki.fi, Internet www.hecer.fi 


\title{
Corruption and Infrastructure at the Country and Regional Level*
}

\begin{abstract}
This paper examines the relationship between corruption and infrastructure at both the country and regional level using the World Bank's Enterprise Surveys data. A statistically significant and considerable relationship is established between the measure of corruption in the macro data and the measures of transportation and electricity infrastructure. Countries with more corruption tend to have worse infrastructure in the eyes of their firms. This link is shown to remain when one uses other measures of corruption and after controlling for GDP per capita, institutional quality and land area. At the regional level, the key result is unchanged. The magnitude and significance of this result is shown to vary by global region. Two stage least squares results, using distance from the equator as an instrument at the macro level support the simple OLS results and allow us to have some confidence that the causality runs from corruption to infrastructure. Finally, it is shown that within country variation in corruption has a significant effect on regional infrastructure.
\end{abstract}

JEL Classification: D73, H54, O18

Keywords: Corruption, infrastructure, cross country, regional variation

Robert Gillanders

Department of Economics

Aalto University

School of Business

P.O. Box 21240

FI-00076 Aalto

FINLAND

e-mail: rgillanders@gmail.com

* I am very grateful to Tine Jeppesen who kindly provided me with a cleaned version of the Enterprise Survey firm level dataset. Steve Billon, Michael Breen, Adrian Corcoran and Marko Terviö provided useful comments and suggestions. 


\section{Introduction}

When asked to name some of the key problems facing developing countries, many people, experts and layman alike, will answer corruption and infrastructure. The importance of these factors is borne out by those on the ground. For example, nearly $84 \%$ of firms in Niger feel that corruption is a major constraint to their operations according to the World Bank's Enterprise Surveys (ES). ${ }^{1}$ It is important to note that this is not just a Sub-Saharan African problem. On average, the problem is worst in the Middle East and North Africa region $(57 \%)$ though even in the high-income OECD sample the data show that some firms consider corruption to be a hindrance (14\%). Dissatisfaction with infrastructure is also widespread. In terms of transportation (electricity) infrastructure, $50 \%(63 \%)$ of respondents in Niger identified it as an obstacle. These problems are worst in Sub-Saharan Africa (27\% and $49 \%$ ) but again are still an issue in the high-income OECD sample (11\% and $16 \%)$. The phenomena of corruption and unsatisfactory infrastructure thus seem to be a particular problem in developing and transition countries but are still to be found in richer economies.

Tanzi and Davoodi (1997) was an early exposition of the link between corruption and infrastructural quality. Amongst other findings, they show that corruption is associated with a lower quality of infrastructure across a range of indicators. Del Monte and Papagni (2001) find that corruption has a negative effect on the efficiency (in terms of economic growth) of expenditures on public investment in a sample of Italian regions. Bose, Capasso and Murshid (2008) present a model in which corruption is only detrimental to infrastructural quality once it passes a threshold and supports this argument with empirical evidence. Using an early version of the ES data in conjunction with other data, Kenny (2009) finds a correlation between measures of corruption and some measures of infrastructural quality, though as Kenny himself emphasises, the sample size available to him is very small. The first contribution of this paper is to revisit this question with a new dataset that arguably contains more satisfactory measures of both variables. Corruption emerges as a significant correlate of infrastructural quality in line with many existing papers in this literature.

These papers for the most part do not address issues of endogeneity, though many of them are not attempts to establish a causal relationship. Endogeneity is a concern in two regards when investigating the link between corruption and infrastructure. Firstly, the possibility of common and unobservable causes for both the level of corruption and quality of infrastructure cannot be discounted. Secondly, it is conceivable that countries or regions with worse infrastructure will tend to have more corruption. The second contribution made here is to address this endogeneity. Corruption is shown to be an important factor in determining infrastructure.

\footnotetext{
${ }^{1}$ The statistics quoted are taken from the most recent data available for each country which is not necessarily the same year for each country.
} 
The final and most important contribution of this paper is to extend the analysis to the regional level. The link between regional, or local, infrastructure and regional corruption has not yet been studied widely and the ES data allows one to do so. Two important results emerge from this exercise. Firstly, a higher level of corruption in a region is associated with poorer infrastructure. Secondly, the variation from the national average in corruption is associated with both a lower level of infrastructure both in general and in relation to the national average.

These results have important policy implications. If, as is evidenced by the data, more corrupt countries have infrastructure that is not acceptable in the eyes of business, then any policy that sees infrastructure as the path to development needs to recognise this. In terms of regional development, the results suggest that regional development and infrastructural policies need to take account of both the local degree of corruption and of the within country variation. Corruption has been shown to have negative relationships with important factors such as growth (e.g. Mauro (1995)), foreign direct investment (e.g. Wei (2000)), inequality and poverty (e.g. Gupta, Davoodi and Alonso-Terme (2002)), individual well-being (e.g. Gillanders (2011)), environmental policy (e.g. Fredriksson and Svensson (2003)), inflation (e.g. Al-Marhubi (2000)), attitudes to the political system (e.g. Anderson and Tverdova (2003)) and the quality of regulation (e.g. Breen and Gillanders (2012)). The potential importance of infrastructure for growth has been examined by theorists such as Agénor (2010) while Esfahani and Ramirez (2003) present a structural model and conclude that infrastructure is a considerable boon in terms of GDP. Wang (2003) finds that electricity matters for child mortality and Fernald (1999) finds that transport infrastructure is good for the productivity of firms in vehicle intensive industries. Thus, there is a large body of evidence that both corruption and infrastructure are important factors in an economy. The remainder of this paper proceeds as follows. Section 2 describes the data, sections 3 and 4 present the country level and regional level results respectively, and the final section concludes.

\section{Data}

The main source of data on the variables of interest for this paper is the World Bank's Enterprise Surveys (ES) database. These representative firm level surveys collect information on a wide range of topics and have been widely used in empirical work. The ES team provide country level averages of the key variables and I generate the regional level indicators from the raw firm level data. ${ }^{2}$ Unfortunately, the data is not suitable for panel data analysis as the surveys have been conducted only once in some countries and in different years. The

\footnotetext{
${ }^{2}$ See http://www.enterprisesurveys.org/Methodology for the full methodology.
} 
ES infrastructure and corruption variables used here come from survey questions that ask firms to state how much of an obstacle various factors are to their operation. Respondents can answer on a scale from zero (no obstacle) to four (very severe obstacle) on each factor. These measures have some important advantages over other commonly used variables.

Firstly, as opposed to the often used Corruption Perceptions Index (CPI) compiled by Transparency International (TI), the ES corruption measure is not based on the perceptions of experts. It is a measure of perceptions but the perceptions of those directly affected by and who have experienced corruption. Another popular measure of corruption is the World Bank's Control of Corruption (CC) measure produced by Kaufmann, Kraay and Mastruzzi (2010). As CC is highly correlated with the World Bank's Rule of Law (RL) measure of institutional quality and other such variables, it is difficult for one to separate and identify the effects of corruption and general institutional quality when they are included simultaneously. ${ }^{3}$ Both of these alternative measures of corruption will be used in checks of the robustness of the main result. These variables cannot be used when we turn to examine regional level results as they are only computed at the national level.

The infrastructure variables used here measure how much firms perceive each type of infrastructure to be an obstacle whereas the infrastructure variables used by Tanzi and Davoodi (1997), Bose, Capasso and Murshid (2008) and others are intended as measures of the quality of infrastructure. It is well known that these quality measures are far from perfect. For example, Bose et al. point out that taking the length of paved roads as a measure of transportation infrastructure ignores the issue of width and measures based on the proportion of roads that are paved lead to large countries being penalised [Bose, Capasso and Murshid (2008); pp1178]. Like the ES corruption variable, the infrastructure measures I shall use here are based on how much of an obstacle firms find the type of infrastructure. Holding countries with different levels of development and different types of economy and production to the same external standards of infrastructure, even if they are perfectly objective, would be an inferior choice in the context of the current question. The specific infrastructure questions used relate to transportation infrastructure and electricity infrastructure at the country level, and to these two plus telecommunications infrastructure at the regional level.

The variables of interest are the percentage of firms in a country or region who responded that the factor in question was a major or very severe obstacle to their operations. Figures 1 and 2 plot the macro relationships between infrastructure and corruption using the pooled data. Both figures show a relationship between the two with it being particularly strong in the case of transportation infrastructure. The data on distance from the equator were obtained from Parker (1997). All other variables were obtained from the World Development Indicators (WDI) and the TI and ES datasets.

\footnotetext{
${ }^{3}$ The absolute value of the raw correlation between $\mathrm{RL}$ and $\mathrm{CC}$ in the sample is 0.87 whereas it is 0.40 between RL and the ES corruption measure.
} 
Figure 1: Country Level Transport Infrastructure and Corruption

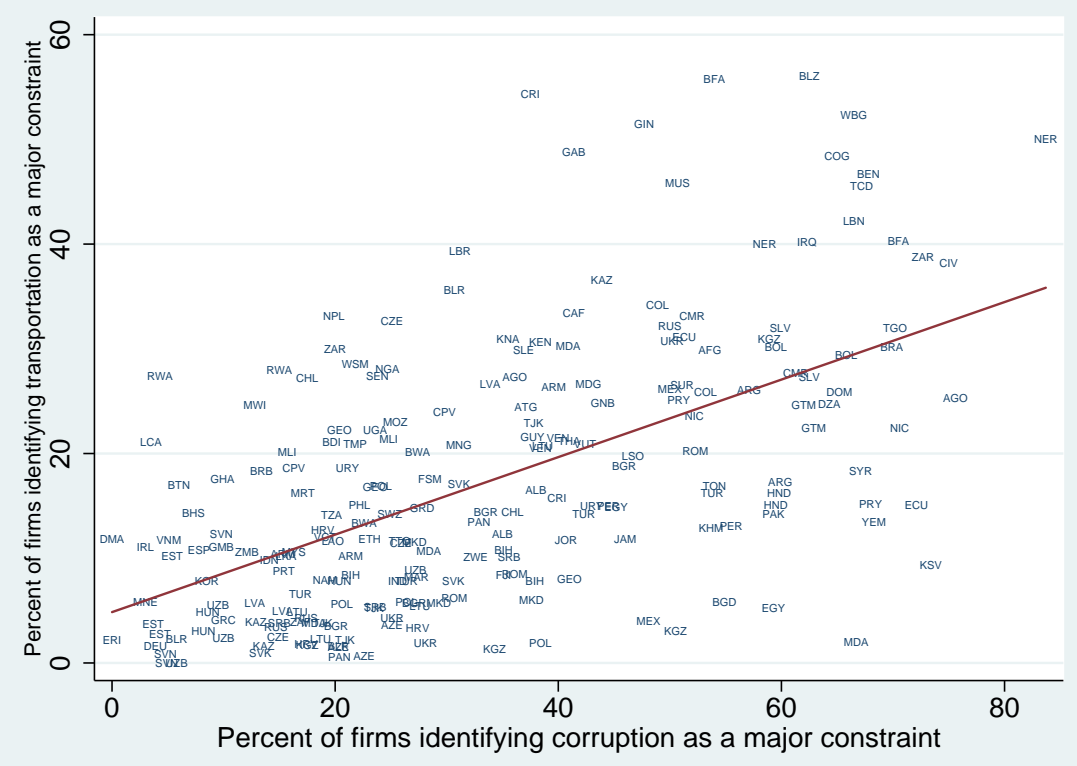

Figure 2: Country Level Electricity Infrastructure and Corruption

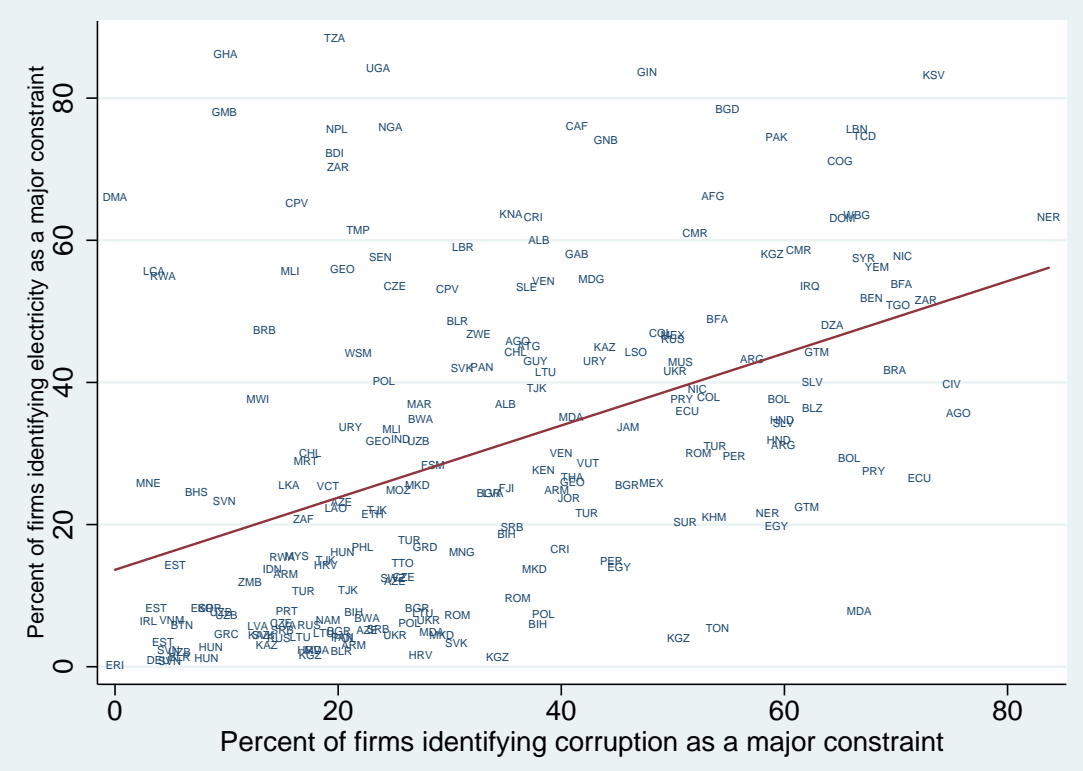




\section{Country Level Results}

The general form of the model used in estimating the relationship between corruption and infrastructure quality is of the form:

$$
I N F_{i t}=\alpha+\beta_{1} C O R_{i t}+\beta_{2} G D P P C_{i t}+\beta_{3} I N S T_{i t}+\beta_{4} A R E A_{i t}+\epsilon_{i t}
$$

where $I N F_{i t}$ is either the ES country level measure of transport or of electricity infrastructure, $C O R_{i t}$ a measure of corruption, $G D P P C_{i t}$ is the natural logarithm of GDP per capita, $A R E A_{i t}$ is the natural logarithm of land area in square kilometres, and $\epsilon_{i t}$ is an error term of the standard type.

The model is estimated using pooled OLS due to the fact that, as mentioned in Section 2 above, the ES data does not (as of yet) form a panel of sufficient dimension. As unobserved heterogeneity is always a concern, it will be important to check that the main results are robust to the inclusion of country specific dummy variables. The additional controls are included to capture the potential deep determinants of a country's infrastructure. The first is GDP per capita as a control for the level of economic development and prosperity. This data comes from the WDI. The second is institutional quality as measured by the World Bank's Rule of Law variable. I include this variable as there is a long standing literature that has explored the relationship between institutional quality and aspects of infrastructural quality. Henisz (2002) provides an overview of this literature. Finally, land area is controlled for as it seems sensible to allow for countries of different sizes to have different levels of infrastructure, regardless of other considerations.

Table 1 presents results obtained from running this model on the ES measures of transport (Panel A) and electricity (Panel B) infrastructure. The first column of each panel establishes that there is a statistically significant relationship between the ES measure of corruption and both of the infrastructure variables. Further, the $\mathrm{R}^{2}$ statistics indicate that a large proportion of the variance in infrastructural quality across countries can be accounted for by corruption alone. These large $\mathrm{R}^{2}$ statistics are not present in columns 2 and 3 where alternative measures of corruption are used, though corruption remains highly significant (though the signs differ from Column 1 as these variables give bigger numbers to countries with less corruption). This association remains in the face of country fixed effects, as can be seen in Column 4.

More importantly, the magnitude of the association is economically meaningful. The results of the first column indicate that a one standard deviation - approximately $20 \%$ - increase in the corruption variable is associated with an increase of roughly $7 \%$ and $10 \%$ in the transportation and electricity infrastructure variables respectively. In both cases this is about 0.4 of a standard deviation. This is about half of the difference between the Europe 
Table 1: Country Level Results I: Baseline Results

\begin{tabular}{|c|c|c|c|c|c|}
\hline \multicolumn{6}{|c|}{ Panel A: Transport Infrastructure } \\
\hline & (1) & $(2)$ & (3) & (4) & (5) \\
\hline Constant & $\begin{array}{c}4.857^{* * * *} \\
(1.219)\end{array}$ & $\begin{array}{c}23.539^{* * *} \\
(2.343)\end{array}$ & $\begin{array}{c}16.220^{* * *} \\
(0.850)\end{array}$ & $\begin{array}{l}11.835^{*} \\
(6.714)\end{array}$ & $\begin{array}{c}27.429^{* * *} \\
(7.193)\end{array}$ \\
\hline Enterprise Surveys Corruption Measure & $\begin{array}{c}0.370^{* * * *} \\
(0.038)\end{array}$ & & & $\begin{array}{c}0.337^{* * *} \\
(0.125)\end{array}$ & $\begin{array}{c}0.385^{* * *} \\
(0.042)\end{array}$ \\
\hline Corruption Perceptions Index & & $\begin{array}{c}-1.867^{* * *} \\
(0.598)\end{array}$ & & & \\
\hline Control of Corruption Index & & & $\begin{array}{c}-2.824^{* *} \\
(1.149)\end{array}$ & & \\
\hline Natural Log of GDP Per Capita & & & & & $\begin{array}{c}-2.585^{* * *} \\
(0.806)\end{array}$ \\
\hline Rule of Law Index & & & & & $\begin{array}{l}3.308^{* *} \\
(1.406)\end{array}$ \\
\hline $\begin{array}{l}\text { Natural Log of Land Area in Square } \\
\text { Kilometres }\end{array}$ & & & & & $\begin{array}{l}-0.269 \\
(0.340)\end{array}$ \\
\hline Country Fixed Effects & NO & NO & NO & YES & NO \\
\hline $\mathrm{R}^{2}$ & 0.32 & 0.04 & 0.02 & 0.82 & 0.35 \\
\hline$N$ & 224 & 205 & 220 & 224 & 216 \\
\hline \multicolumn{6}{|c|}{ Panel B: Electricity Infrastructure } \\
\hline Constant & $\begin{array}{c}(1) \\
13.646^{* * *} \\
(2.950)\end{array}$ & $\begin{array}{c}(2) \\
45.872^{* * *} \\
(4.299)\end{array}$ & $\begin{array}{c}(3) \\
28.356^{* * *} \\
(1.578)\end{array}$ & $\begin{array}{c}(4) \\
35.608^{* * *} \\
(11.177)\end{array}$ & $\begin{array}{c}(5) \\
77.707^{* * * *} \\
(16.366)\end{array}$ \\
\hline Enterprise Surveys Corruption Measure & $\begin{array}{c}0.508^{* * * *} \\
(0.069)\end{array}$ & & & $\begin{array}{c}0.571^{* * *} \\
(0.209)\end{array}$ & $\begin{array}{c}0.501^{* * *} \\
(0.074)\end{array}$ \\
\hline Corruption Perceptions Index & & $\begin{array}{c}-4.562^{* * *} \\
(1.107)\end{array}$ & & & \\
\hline Control of Corruption Index & & & $\begin{array}{c}-6.277^{* * *} \\
(2.155)\end{array}$ & & \\
\hline Natural Log of GDP Per Capita & & & & & $\begin{array}{c}-6.121^{* * *} \\
(1.709)\end{array}$ \\
\hline Rule of Law Index & & & & & $\begin{array}{c}3.189 \\
(2.626)\end{array}$ \\
\hline $\begin{array}{l}\text { Natural Log of Land Area in Square } \\
\text { Kilometres }\end{array}$ & & & & & $\begin{array}{l}-1.525^{*} \\
(0.792)\end{array}$ \\
\hline Country Fixed Effects & NO & NO & NO & YES & NO \\
\hline $\mathrm{R}^{2}$ & 0.19 & 0.07 & 0.04 & 0.85 & 0.26 \\
\hline$N$ & 224 & 205 & 220 & 224 & 216 \\
\hline
\end{tabular}

Notes: Robust standard errors in parentheses. ${ }^{*}, * *$ and $* * *$ indicate significance at the $10 \%, 5 \%$ and $1 \%$ levels respectively. 
and Central Asia sample and the Africa sample in terms of transport infrastructure and one third of the difference between the two in terms of electricity infrastructure.

The final column includes the other potential determinants of infrastructural quality outlined above. GDP per capita is significantly correlated with both measures with richer countries tending to have better infrastructure as one would expect. Firms in countries with better institutions tend to be less satisfied with infrastructure, though this relationship is only significant in Panel A. This is perhaps contrary to what one would expect a priori. One explanation is that in countries with good institutions, there is a higher expectation of, say, good roads and that this effect is greater than any tendency for good institutions to provide better infrastructure. Another plausible explanation is that the institutional quality is endogenous in much the same way that corruption may be. Finally, there is no strong evidence that the size of a country plays a role.

Having established that there is a relationship in general, it is good practice to see if this relationship varies by geographical region. For example, Asiedu (2002) and Blonigen and Wang (2005) have demonstrated this to be an worthwhile exercise in the FDI literature. This is particularly important if one wishes to offer even broad policy advice to developing countries. Table 2 divides the sample into four general regions - Africa (including North Africa), Europe and Central Asia (ECA), Latin America and Caribbean (LAC), and the Rest of the World (RoW).

Panel A shows that in most groups the relationship between corruption and transport infrastructure is significant and sizeable. Only in Column 8 is the corruption variable insignificant. This is the RoW sample with the additional controls. It should be borne in mind that the RoW sample is a rather small and heterogeneous sample. Thus the RoW results should be treated with extra caution. The coefficient is largest in Africa and it is also worth noting that the size of the country plays a significant role in this sample with larger countries tending to have better transport infrastructure in the eyes of firms. The story seems to be very different when it comes to electricity infrastructure, as can be seen in Panel B. In this case corruption only has a significant association with infrastructure in the ECA sample. Once again, country size is inversely related to firms' perceptions of infrastructure in Africa though not in either the ECA or LAC samples. A general point that emerges from these tables is that there is a relationship between corruption and infrastructure but that the efficacy of any policy based on this relationship will be dependent on where the policy is to be carried out and on the type of infrastructure.

Of course, to be able to offer credible policy advice one must provide at least a certain degree of evidence that the relationship is free of endogeneity bias. As outlined above, there are convincing arguments that the prevalence of corruption and the degree of infrastructural quality are endogenous. Distance from the equator (DE) is used as an instrumental variable 
Table 2: Country Level Results II: Sample Splits

\begin{tabular}{|c|c|c|c|c|c|c|c|c|}
\hline \multicolumn{9}{|c|}{ Panel A: Transport Infrastructure } \\
\hline & (1) & (2) & (3) & (4) & (5) & (6) & (7) & (8) \\
\hline & \multicolumn{2}{|c|}{ Africa } & \multicolumn{2}{|c|}{ Europe \& Central Asia } & \multicolumn{2}{|c|}{ Americas \& Caribbean } & \multicolumn{2}{|c|}{ Rest of the World } \\
\hline Constant & $\begin{array}{c}11.717^{* * *} \\
(2.341)\end{array}$ & $\begin{array}{c}43.563^{* * *} \\
(15.799)\end{array}$ & $\begin{array}{c}1.843 \\
(1.573)\end{array}$ & $\begin{array}{l}-13.976 \\
(13.648)\end{array}$ & $\begin{array}{c}14.078^{* * *} \\
(3.038)\end{array}$ & $\begin{array}{c}15.282 \\
(16.114)\end{array}$ & $\begin{array}{c}10.025^{* * *} \\
(3.402)\end{array}$ & $\begin{array}{c}34.346 \\
(25.323)\end{array}$ \\
\hline Enterprise Surveys Corruption Measure & $\begin{array}{c}0.391^{* * *} \\
(0.062)\end{array}$ & $\begin{array}{c}0.404^{* * *} \\
(0.070)\end{array}$ & $\begin{array}{c}0.307^{* * *} \\
(0.075)\end{array}$ & $\begin{array}{c}0.345^{* * *} \\
(0.074)\end{array}$ & $\begin{array}{l}0.172^{* *} \\
(0.064)\end{array}$ & $\begin{array}{l}0.312^{* *} \\
(0.128)\end{array}$ & $\begin{array}{l}0.242^{* *} \\
(0.114)\end{array}$ & $\begin{array}{c}0.070 \\
(0.096)\end{array}$ \\
\hline Natural Log of GDP Per Capita & & $\begin{array}{r}-2.071 \\
(1.999)\end{array}$ & & $\begin{array}{c}0.885 \\
(1.712)\end{array}$ & & $\begin{array}{c}-0.289 \\
(1.833)\end{array}$ & & $\begin{array}{c}-0.345 \\
(3.020)\end{array}$ \\
\hline Rule of Law Index & & $\begin{array}{l}-2.258 \\
(3.609)\end{array}$ & & $\begin{array}{c}1.072 \\
(2.574)\end{array}$ & & $\begin{array}{c}4.033 \\
(2.911)\end{array}$ & & $\begin{array}{c}0.103 \\
(3.056)\end{array}$ \\
\hline $\begin{array}{l}\text { Natural Log of Land Area in Square } \\
\text { Kilometres }\end{array}$ & & $\begin{array}{l}-1.651^{* *} \\
(0.811)\end{array}$ & & $\begin{array}{c}0.699 \\
(0.634)\end{array}$ & & $\begin{array}{l}-0.345 \\
(0.616)\end{array}$ & & $\begin{array}{c}-1.578^{* *} \\
(0.690)\end{array}$ \\
\hline $\mathrm{R}^{2}$ & 0.40 & 0.50 & 0.25 & 0.29 & 0.10 & 0.15 & 0.19 & 0.20 \\
\hline$N$ & 54 & 51 & 96 & 96 & 47 & 46 & 27 & 23 \\
\hline \multicolumn{9}{|c|}{ Panel B: Electricity Infrastructure } \\
\hline & (1) & (2) & (3) & (4) & (5) & (6) & (7) & (8) \\
\hline & \multicolumn{2}{|c|}{ Africa } & \multicolumn{2}{|c|}{ Europe \& Central Asia } & \multicolumn{2}{|c|}{ Americas \& Caribbean } & \multicolumn{2}{|c|}{ Rest of the World } \\
\hline Constant & $\begin{array}{c}41.802^{* * *} \\
(7.382)\end{array}$ & $\begin{array}{c}118.258^{* * *} \\
(24.304)\end{array}$ & $\begin{array}{l}-0.426 \\
(1.573)\end{array}$ & $\begin{array}{l}-18.541 \\
(20.164)\end{array}$ & $\begin{array}{c}37.647^{* * *} \\
(7.130)\end{array}$ & $\begin{array}{c}44.301 \\
(31.911)\end{array}$ & $\begin{array}{l}11.613^{*} \\
(6.633)\end{array}$ & $\begin{array}{c}72.096 \\
(51.468)\end{array}$ \\
\hline Enterprise Surveys Corruption Measure & $\begin{array}{c}0.153 \\
(0.143)\end{array}$ & $\begin{array}{c}0.118 \\
(0.169)\end{array}$ & $\begin{array}{c}0.664^{* * *} \\
(0.136)\end{array}$ & $\begin{array}{c}0.691^{* * *} \\
(0.131)\end{array}$ & $\begin{array}{c}-0.017 \\
(0.135)\end{array}$ & $\begin{array}{c}0.147 \\
(0.226)\end{array}$ & $\begin{array}{c}0.706^{* * *} \\
(0.156)\end{array}$ & $\begin{array}{l}0.598^{* *} \\
(0.209)\end{array}$ \\
\hline Natural Log of GDP Per Capita & & $\begin{array}{l}-4.589 \\
(3.401)\end{array}$ & & $\begin{array}{c}4.151 \\
(2.827)\end{array}$ & & $\begin{array}{l}-0.510 \\
(3.552)\end{array}$ & & $\begin{array}{l}-7.336 \\
(4.967)\end{array}$ \\
\hline Rule of Law Index & & $\begin{array}{l}-7.969 \\
(7.717)\end{array}$ & & $\begin{array}{l}-4.674 \\
(4.108)\end{array}$ & & $\begin{array}{c}3.305 \\
(4.956)\end{array}$ & & $\begin{array}{l}-8.280 \\
(6.354)\end{array}$ \\
\hline Natural Log of Land Area in Square & & $-4.068^{* *}$ & & -1.299 & & -0.794 & & -0.749 \\
\hline Kilometres & & $(1.738)$ & & $(1.056)$ & & $(0.970)$ & & $(2.145)$ \\
\hline $\mathrm{R}^{2}$ & 0.02 & 0.19 & 0.34 & 0.36 & 0.00 & 0.04 & 0.37 & 0.44 \\
\hline$N$ & 54 & 51 & 96 & 96 & 47 & 46 & 27 & 23 \\
\hline
\end{tabular}

Notes: Robust standard errors in parentheses. ${ }^{*},{ }^{* *}$ and ${ }^{* * *}$ indicate significance at the $10 \%, 5 \%$ and $1 \%$ levels respectively. 
Table 3: Country Level Results III: IV Results

\begin{tabular}{|c|c|c|c|c|}
\hline & (1) & (2) & (3) & (4) \\
\hline Type of Infrastructure: & \multicolumn{2}{|c|}{ Transport } & \multicolumn{2}{|c|}{ Electricity } \\
\hline Constant & $\begin{array}{c}-17.363^{* * *} \\
(5.474)\end{array}$ & $\begin{array}{l}23.360^{*} \\
(13.168)\end{array}$ & $\begin{array}{c}-32.741^{* * *} \\
(11.223)\end{array}$ & $\begin{array}{c}70.149^{* * *} \\
(27.011)\end{array}$ \\
\hline Enterprise Surveys Corruption Measure & $\begin{array}{c}1.030^{* * *} \\
(0.169)\end{array}$ & $\begin{array}{c}1.128^{* * *} \\
(0.205)\end{array}$ & $\begin{array}{c}1.886^{* * *} \\
(0.364)\end{array}$ & $\begin{array}{c}1.881^{* * *} \\
(0.391)\end{array}$ \\
\hline Natural Log of GDP Per Capita & & $\begin{array}{c}-4.381^{* * *} \\
(1.523)\end{array}$ & & $\begin{array}{c}-9.457^{* * *} \\
(3.323)\end{array}$ \\
\hline Rule of Law Index & & $\begin{array}{c}12.916^{* * *} \\
(3.599)\end{array}$ & & $\begin{array}{c}21.035^{* * *} \\
(7.104)\end{array}$ \\
\hline $\begin{array}{l}\text { Natural Log of Land Area in Square } \\
\text { Kilometres }\end{array}$ & & $\begin{array}{l}-0.644 \\
(0.597)\end{array}$ & & $\begin{array}{l}-2.223^{*} \\
(1.290)\end{array}$ \\
\hline $\begin{array}{l}\text { First Stage F Statistic } \\
N\end{array}$ & $\begin{array}{c}28.76 \\
224\end{array}$ & $\begin{array}{c}21.51 \\
216\end{array}$ & $\begin{array}{c}28.76 \\
224\end{array}$ & $\begin{array}{c}21.51 \\
216\end{array}$ \\
\hline
\end{tabular}

Notes: Robust standard errors in parentheses. ${ }^{*},{ }^{*}$ and $* * *$ indicate significance at the $10 \%, 5 \%$ and $1 \%$ levels respectively. The instrument used for the corruption variable is distance from the equator.

in an attempt to obtain estimates which are clean of this endogeneity. DE has been used as an instrument for general institutional quality in a range of papers such as Hall and Jones (1999) and Rodrik, Subramanian and Trebbi (2004). Treisman (2007) captures the intuition behind using DE as an instrument for corruption well (when arguing that DE would not make a good instrument for looking at the effect of economic development on corruption): "If settler mortality led European colonists to create more exploitative, unaccountable governments in countries with more tropical climates, closeness to the Equator might slow economic development by encouraging corruption" (p226). ${ }^{4}$ Put at its most simple, the argument can be represented as: tropical climate $\rightarrow$ more exploitative colonial government $\rightarrow$ more corrupt post-colonial government.

The results of this 2SLS exercise are presented in Table 3. For both of the infrastructure variables, corruption is a statistically significant factor. All specifications have first stage $\mathrm{F}$ statistics that are satisfactory by the standard of the Staiger and Stock (1997) rule of thumb. The IV strategy will be invalid if the above relationship is not strong enough or if DE is a determinant of infrastructural quality outside of the instrument's effect on corruption. The former can be tested for using the standard weak instrument rule of thumb while the later could be looked at using tests of over-identifying restrictions if there were more instruments. ${ }^{5}$

\footnotetext{
${ }^{4}$ This quote suggests that the settler mortality instrument of Acemoglu, Johnson and Robinson (2001) would perhaps make a good instrument. However, this would lead to a greatly reduced sample that was restricted to countries that had been colonised. Therefore it is not an avenue that I pursue here.

${ }^{5}$ When I use the ethnic fractionalisation measure of Alesina, Devleeschauwer, Easterly, Kurlat and Wacziarg (2003) as an additional instrument both the first stage F statistics and tests of over-identifying
} 
Figure 3: Within Country Variation in Corruption

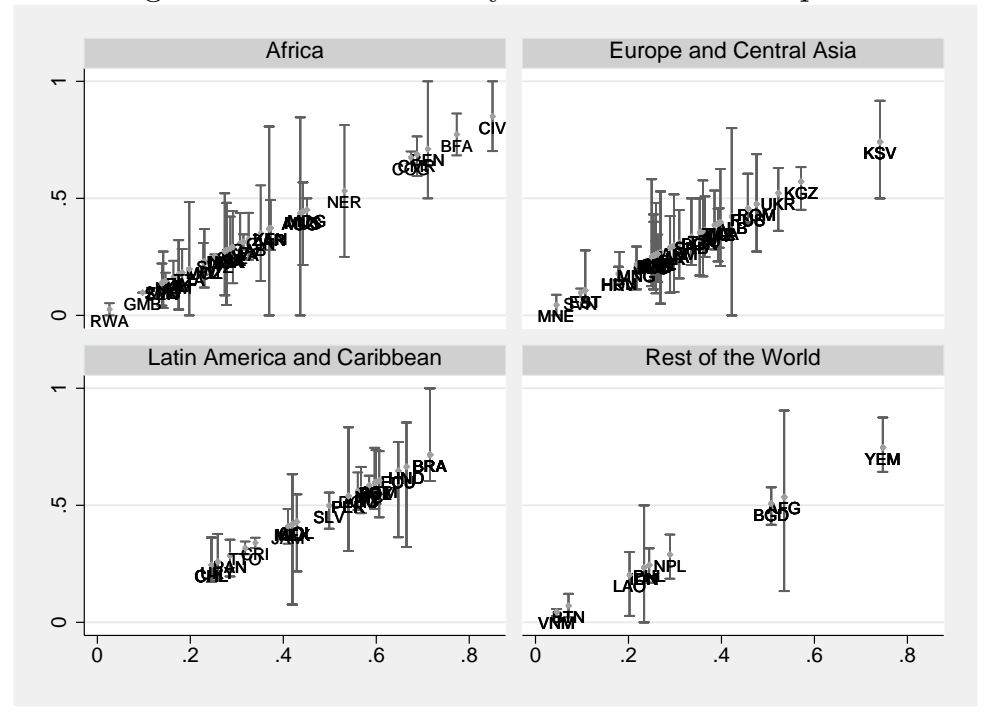

\section{Regional Level Results}

The previous section established that the data points to a strong relationship between the level of corruption in a country and its infrastructure and provided some evidence of an effect running from corruption to infrastructure. The ES data provide a unique opportunity to take the analysis to the regional level. Corruption is more often than not spoken of as if there were no within country variation, perhaps because the most widely used measures exist only at the country level. This is also somewhat true of discussions of infrastructure in this literature. However, there are strong reasons to think that such variation may be large. Certain regions may be more corrupt for cultural, historical or general economic reasons while infrastructure may vary by region for similar reasons, in addition to geographical considerations and perhaps due to variation in corruption. Figures 3 and 4 show that such variation exists in the data. The upper and lower points on the bars show the maximum and minimum regional values for each country while the points show the country average (where the data are pooled over time). It is worth noting that this variation does not seem correlate with the level i.e. the length of the bars does not tend to increase or decrease in any obvious (linear) way as we move along the horizontal axes.

It must be noted that these regions are not always necessarily real administrative or geographical divisions. For example, Argentina is divided into Buenos Aires, Chaco, Cordoba, Mendoza and Rosario while Armenia by contrast is divided into North, South East, South

restrictions are satisfactory. The results from this exercise lead to identical conclusions as those presented here and are available on request. 
Figure 4: Within Country Variation in Transport Infrastructure

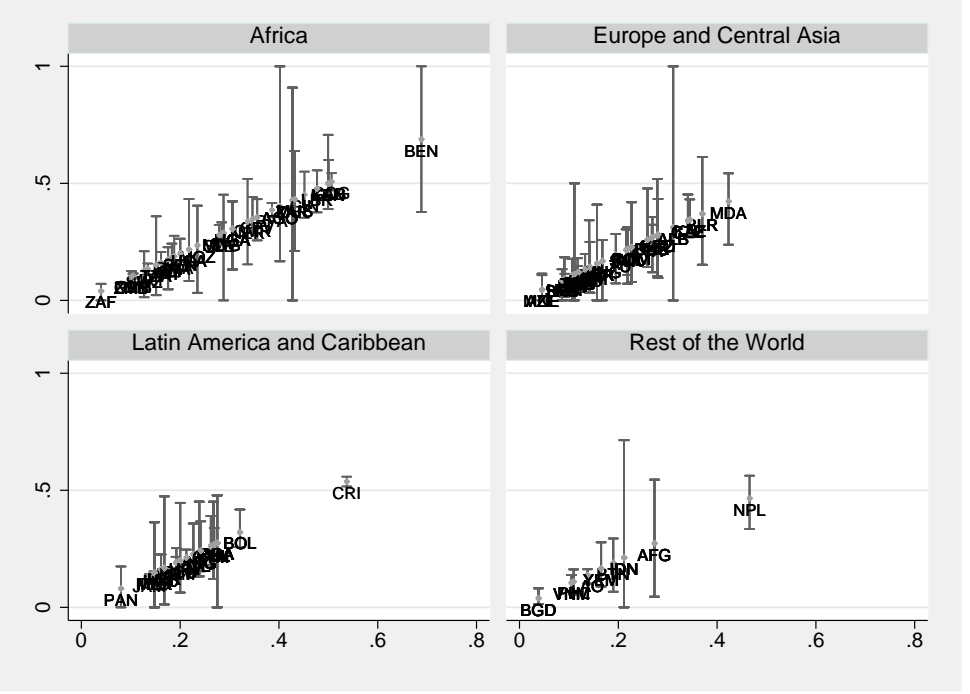

West and Yerevan. Therefore one must bear in mind that the data may be somewhat noisy in general and particularly so in some countries. I drop those countries that have only have one region. These are mostly very small countries such as Burundi and Fiji. Each observation is obtained by averaging the firm level data for each region (in each year where applicable).

In addition to the two infrastructure variables available in the macro data, the firm level dataset contains a question that asks how much of an obstacle telecommunications is to the firm's current operations. Telecommunication infrastructure is obviously an important element in the modern world. The ES measure has an advantage over the often used number of telephone mainlines variable in that, as Wallsten (2001) points out, people can have more than one line and some lines may be used by multiple people (p6). There is no regional GDP variable in the dataset so, as a (somewhat crude) proxy, I use the average total cost of labour to control for income. In addition, I control for the percentage of sales that are national. It seems plausible that regions which produce more for the domestic market than the foreign market could require different types of infrastructure and to different degrees.

Table 4 presents the results from estimating OLS regressions using this regional data. In the case of each of the infrastructure variables, corruption is a sizeable and significant correlate. Corruption can only explain a small proportion of the variation in infrastructure on its own as can be seen from the $\mathrm{R}^{2}$ statistics in columns 1,4 and 7 . Given the wide range of plausible determinants of regional infrastructure this is not surprising. The inclusion of country fixed effects does not cause the corruption variable to lose its significance nor does the inclusion of the additional controls. These controls are interesting in their own right. Regions with a higher average total cost of labour tend to have better reported 
Table 4: Region Level Results I: Baseline Results

\begin{tabular}{|c|c|c|c|c|c|c|c|c|c|}
\hline & (1) & (2) & (3) & (4) & (5) & (6) & (7) & (8) & (9) \\
\hline Type of Infrastructure: & \multicolumn{3}{|c|}{ Transport } & \multicolumn{3}{|c|}{ Electricity } & \multicolumn{3}{|c|}{ Telecommunications } \\
\hline Constant & $\begin{array}{c}0.167^{* * *} \\
(0.017)\end{array}$ & $\begin{array}{l}0.176^{* *} \\
(0.076)\end{array}$ & $\begin{array}{c}0.021 \\
(0.124)\end{array}$ & $\begin{array}{c}0.307^{* * *} \\
(0.025)\end{array}$ & $\begin{array}{c}0.573^{* * *} \\
(0.109)\end{array}$ & $\begin{array}{c}0.650^{* * *} \\
(0.182)\end{array}$ & $\begin{array}{c}0.091^{* * *} \\
(0.016)\end{array}$ & $\begin{array}{c}0.174^{* * *} \\
(0.057)\end{array}$ & $\begin{array}{c}0.086 \\
(0.166)\end{array}$ \\
\hline Enterprise Surveys Corruption Measure & $\begin{array}{l}0.170^{* * *} \\
(0.043)\end{array}$ & $\begin{array}{c}0.182^{* *} \\
(0.086)\end{array}$ & $\begin{array}{c}0.180^{* * *} \\
(0.042)\end{array}$ & $\begin{array}{c}0.300^{* * *} \\
(0.054)\end{array}$ & $\begin{array}{l}0.171^{* *} \\
(0.082)\end{array}$ & $\begin{array}{c}0.339^{* * *} \\
(0.056)\end{array}$ & $\begin{array}{c}0.354^{* * *} \\
(0.046)\end{array}$ & $\begin{array}{c}0.287^{* * *} \\
(0.063)\end{array}$ & $\begin{array}{c}0.341^{* * *} \\
(0.045)\end{array}$ \\
\hline $\begin{array}{l}\text { Natural Log of Average Total Cost of } \\
\text { Labour }\end{array}$ & & & $\begin{array}{l}-0.002 \\
(0.006)\end{array}$ & & & $\begin{array}{c}-0.041^{* * *} \\
(0.008)\end{array}$ & & & $\begin{array}{r}0.022^{* * *} \\
(0.006)\end{array}$ \\
\hline Average $\%$ of Sales That Are National & & & $\begin{array}{l}0.002^{*} \\
(0.001)\end{array}$ & & & $\begin{array}{c}0.002 \\
(0.002)\end{array}$ & & & $\begin{array}{r}-0.003^{* *} \\
(0.001)\end{array}$ \\
\hline Country Fixed Effects & NO & YES & NO & NO & YES & NO & NO & YES & NO \\
\hline $\mathrm{R}^{2}$ & 0.05 & 0.51 & 0.08 & 0.08 & 0.73 & 0.18 & 0.18 & 0.53 & 0.25 \\
\hline$N$ & 438 & 438 & 437 & 438 & 438 & 437 & 402 & 402 & 402 \\
\hline
\end{tabular}

Notes: Robust standard errors in parentheses. ${ }^{*}, * *$ and ${ }^{* * *}$ indicate significance at the $10 \%, 5 \%$ and $1 \%$ levels respectively.

electricity infrastructure and worse telecommunications infrastructure on average. Regions that produce more for the domestic market tend to have firms that are more satisfied with the state of telecommunications infrastructure.

Table 5 splits the sample in the same way as was done above. Once again, the motivation for this is that it is reasonable to expect that the relationship under study will vary across the globe. Briefly, we can see that this is indeed the case. In Africa, for example, there is no significant relationship between corruption and electricity infrastructure (Panel B) but there is with the other infrastructure measures. The magnitude of the relationship also varies by global region. In some cases, corruption alone can explain a large proportion of the variation in infrastructure (e.g. Column 1 of Panel C). Thus the results of this region level analysis support those of the country level analysis above.

There are no variables that can serve as instruments in the region level data - certainly none that are fully satisfactory. This is unfortunate as the same arguments for endogeneity made at the country level can be made at the regional level. The fact that the IV results at the country level were in line with the OLS results does not necessarily mean that the same would be true at the regional level. Two somewhat convincing instruments are firms' perceptions of how much of a constraint the courts system and customs and regulation procedures are to their operations. These instruments have acceptable first stage $\mathrm{F}$ statistics and give results in line with the OLS results presented in Table 4 and are available on request. The issue with these exercises is that it is hard to argue that whatever factors may determine both corruption and infrastructure do not also determine these instruments.

The region level data allows one to look at within country variation. We have seen that 
Table 5: Region Level Results II: Sample Splits

\begin{tabular}{|c|c|c|c|c|c|c|c|c|}
\hline \multicolumn{9}{|c|}{ Panel A: Transport Infrastructure } \\
\hline & (1) & $(2)$ & (3) & $(4)$ & (5) & (6) & (7) & (8) \\
\hline & \multicolumn{2}{|c|}{ Africa } & \multicolumn{2}{|c|}{ Europe \& Central Asia } & \multicolumn{2}{|c|}{ Americas \& Caribbean } & \multicolumn{2}{|c|}{ Rest of the World } \\
\hline Constant & $\begin{array}{c}0.182^{* * *} \\
(0.032)\end{array}$ & $\begin{array}{c}0.060 \\
(0.454)\end{array}$ & $\begin{array}{c}0.152^{\text {**** }} \\
(0.034)\end{array}$ & $\begin{array}{l}-0.109 \\
(0.173)\end{array}$ & $\begin{array}{c}0.169^{* * * *} \\
(0.037)\end{array}$ & $\begin{array}{c}-0.027 \\
(0.195)\end{array}$ & $\begin{array}{c}0.134^{* * * *} \\
(0.025)\end{array}$ & $\begin{array}{l}-0.117 \\
(0.288)\end{array}$ \\
\hline Enterprise Surveys Corruption Measure & $\begin{array}{c}0.341^{* * * *} \\
(0.097)\end{array}$ & $\begin{array}{c}0.339^{* * * *} \\
(0.104)\end{array}$ & $\begin{array}{l}0.166^{*} \\
(0.091)\end{array}$ & $\begin{array}{c}0.221^{* * * *} \\
(0.077)\end{array}$ & $\begin{array}{c}0.101 \\
(0.069)\end{array}$ & $\begin{array}{l}0.147^{* *} \\
(0.057)\end{array}$ & $\begin{array}{l}0.129^{*} \\
(0.077)\end{array}$ & $\begin{array}{c}0.117 \\
(0.083)\end{array}$ \\
\hline $\begin{array}{l}\text { Natural Log of Average Total Cost } \\
\text { of Labour }\end{array}$ & & $\begin{array}{c}0.003 \\
(0.016)\end{array}$ & & $\begin{array}{c}0.010 \\
(0.009)\end{array}$ & & $\begin{array}{c}0.029^{* * *} \\
(0.009)\end{array}$ & & $\begin{array}{c}0.009 \\
(0.020)\end{array}$ \\
\hline Average $\%$ of Sales That Are National & & $\begin{array}{c}0.001 \\
(0.004)\end{array}$ & & $\begin{array}{c}0.001 \\
(0.001)\end{array}$ & & $\begin{array}{l}-0.002 \\
(0.002)\end{array}$ & & $\begin{array}{c}0.002 \\
(0.001)\end{array}$ \\
\hline $\mathrm{R}^{2}$ & 0.16 & 0.16 & 0.04 & 0.09 & 0.03 & 0.12 & 0.05 & 0.06 \\
\hline$N$ & 118 & 118 & 158 & 157 & 114 & 114 & 48 & 48 \\
\hline \multicolumn{9}{|c|}{ Panel B: Electricity Infrastructure } \\
\hline & (1) & (2) & (3) & $(4)$ & (5) & (6) & (7) & (8) \\
\hline & \multicolumn{2}{|c|}{ Africa } & \multicolumn{2}{|c|}{ Europe \& Central Asia } & \multicolumn{2}{|c|}{ Americas \& Caribbean } & \multicolumn{2}{|c|}{ Rest of the World } \\
\hline Constant & $\begin{array}{c}0.506^{* * *} \\
(0.043)\end{array}$ & $\begin{array}{c}0.485 \\
(0.480)\end{array}$ & $\begin{array}{c}0.189^{* * * *} \\
(0.038)\end{array}$ & $\begin{array}{c}0.172 \\
(0.299)\end{array}$ & $\begin{array}{c}0.253^{* * *} \\
(0.053)\end{array}$ & $\begin{array}{l}0.362^{*} \\
(0.200)\end{array}$ & $\begin{array}{c}0.113^{* * *} \\
(0.037)\end{array}$ & $\begin{array}{l}0.808^{*} \\
(0.429)\end{array}$ \\
\hline Enterprise Surveys Corruption Measure & $\begin{array}{c}0.104 \\
(0.109)\end{array}$ & $\begin{array}{c}0.174 \\
(0.127)\end{array}$ & $\begin{array}{c}0.498^{\text {**** }} \\
(0.098)\end{array}$ & $\begin{array}{c}0.558^{* * *} \\
(0.084)\end{array}$ & $\begin{array}{c}0.267^{* * * *} \\
(0.101)\end{array}$ & $\begin{array}{c}0.303^{* * *} \\
(0.095)\end{array}$ & $\begin{array}{c}0.845^{* * *} \\
(0.095)\end{array}$ & $\begin{array}{c}0.823^{* * *} \\
(0.098)\end{array}$ \\
\hline $\begin{array}{l}\text { Natural Log of Average Total Cost } \\
\text { of Labour }\end{array}$ & & $\begin{array}{c}-0.040^{* *} \\
(0.018)\end{array}$ & & $\begin{array}{c}0.004 \\
(0.013)\end{array}$ & & $\begin{array}{c}0.013 \\
(0.015)\end{array}$ & & $\begin{array}{c}-0.053^{* *} \\
(0.022)\end{array}$ \\
\hline Average $\%$ of Sales That Are National & & $\begin{array}{c}0.005 \\
(0.004)\end{array}$ & & $\begin{array}{l}-0.001 \\
(0.002)\end{array}$ & & $\begin{array}{l}-0.003 \\
(0.002)\end{array}$ & & $\begin{array}{l}-0.001 \\
(0.003)\end{array}$ \\
\hline $\mathrm{R}^{2}$ & 0.01 & 0.10 & 0.19 & 0.24 & 0.10 & 0.13 & 0.57 & 0.63 \\
\hline$N$ & 118 & 118 & 158 & 157 & 114 & 114 & 48 & 48 \\
\hline \multicolumn{9}{|c|}{ Panel C: Telecommunications Infrastructure } \\
\hline & (1) & $(2)$ & $(3)$ & $(4)$ & $(5)$ & $(6)$ & (7) & $(8)$ \\
\hline & \multicolumn{2}{|c|}{ Africa } & \multicolumn{2}{|c|}{ Europe \& Central Asia } & \multicolumn{2}{|c|}{ Americas \& Caribbean } & \multicolumn{2}{|c|}{ Rest of the World } \\
\hline Constant & $\begin{array}{c}0.033 \\
(0.023)\end{array}$ & $\begin{array}{l}1.203^{* *} \\
(0.522)\end{array}$ & $\begin{array}{l}0.130^{* * * *} \\
(0.037)\end{array}$ & $\begin{array}{c}0.047 \\
(0.251)\end{array}$ & $\begin{array}{l}0.140^{* * *} \\
(0.043)\end{array}$ & $\begin{array}{c}-0.791^{* * *} \\
(0.277)\end{array}$ & $\begin{array}{c}0.039 \\
(0.027)\end{array}$ & $\begin{array}{c}0.684 \\
(0.554)\end{array}$ \\
\hline Enterprise Surveys Corruption Measure & $\begin{array}{r}0.437^{* * *} \\
(0.088)\end{array}$ & $\begin{array}{c}0.399^{* * *} \\
(0.081)\end{array}$ & $\begin{array}{c}0.350^{* * * *} \\
(0.110)\end{array}$ & $\begin{array}{c}0.384^{* * *} \\
(0.102)\end{array}$ & $\begin{array}{l}0.248^{* * *} \\
(0.086)\end{array}$ & $\begin{array}{c}0.282^{* * *} \\
(0.071)\end{array}$ & $\begin{array}{l}0.326^{* *} \\
(0.137)\end{array}$ & $\begin{array}{l}0.392^{* *} \\
(0.151)\end{array}$ \\
\hline $\begin{array}{l}\text { Natural Log of Average Total Cost } \\
\text { of Labour }\end{array}$ & & $\begin{array}{c}0.001 \\
(0.014)\end{array}$ & & $\begin{array}{l}0.022^{*} \\
(0.012)\end{array}$ & & $\begin{array}{c}0.060^{* * *} \\
(0.013)\end{array}$ & & $\begin{array}{l}-0.011 \\
(0.024)\end{array}$ \\
\hline Average $\%$ of Sales That Are National & & $\begin{array}{c}-0.012^{* * *} \\
(0.004)\end{array}$ & & $\begin{array}{l}-0.002 \\
(0.002)\end{array}$ & & $\begin{array}{c}0.001 \\
(0.002)\end{array}$ & & $\begin{array}{l}-0.006 \\
(0.004)\end{array}$ \\
\hline $\mathrm{R}^{2}$ & 0.32 & 0.44 & 0.12 & 0.17 & 0.07 & 0.23 & 0.22 & 0.28 \\
\hline$N$ & 97 & 97 & 155 & 155 & 112 & 112 & 38 & 38 \\
\hline
\end{tabular}

Notes: Robust standard errors in parentheses. ${ }^{*},{ }^{* *}$ and ${ }^{* * *}$ indicate significance at the $10 \%, 5 \%$ and $1 \%$ levels respectively. 
there is considerable variation in both infrastructure and corruption within countries. An obvious next step is to see if the within country variation in infrastructure could be explained by the within country variation in corruption. Some decisions regarding infrastructure, be they decisions regarding the initial provision of infrastructure or the maintenance of existing stocks, are likely to be made at a regional level. In the first column of Table 6 , it can be seen that regions with more corruption than the national average tend to have a lower level of infrastructure in general, while the second and third columns show that regions with more corruption than the national average also tend to have worse infrastructure than the national average. The remaining columns show that this is not the case in all of our sub-sample and infrastructure pairs.

\section{Conclusions}

The results of this paper demonstrate the link between corruption and infrastructure. This link is robust to changes in the measures of both corruption and infrastructure. Another contribution was some evidence that the relationship is one in which corruption determines infrastructure. We also saw that this relationship can vary in both significance and magnitude depending on the type of infrastructure and the part of the world under consideration. Extending the analysis to the regional level, it was shown that the relationship between corruption and infrastructure is also evident. As was the case with the country level analysis, the results vary by pairs defined by global region and type of infrastructure. It was also shown that within country variation matters. Regions with more corruption than their national average tend to have worse infrastructure in general and relative to the national average.

As the Enterprise Surveys continue, it may be become possible to create a panel data set (at least at the country level) and examine some interesting temporal effects such as the effect of lagged corruption on current infrastructure. Another very appealing line of inquiry would be to examine spatial relationships between corruption and infrastructure both within and across countries.

The implications of the results of this paper for policy can only reach the level of generalisation but may be informative for policy makers, in particular for those formulating policy in a development context. A policy that sought development via investment in infrastructure should take note of the setting and type of infrastructure. Further, given the large magnitude of the association and the IV evidence that the relationship runs from corruption to infrastructure, curbing corruption may be a route worth considering if policy makers wish to push for such development. 
Table 6: Region Level Results III: Within Country Variation

\begin{tabular}{|c|c|c|c|c|c|c|c|}
\hline \multicolumn{8}{|c|}{ Panel A: Transport Infrastructure } \\
\hline \multirow{4}{*}{ Constant } & (1) & (2) & (3) & (4) & (5) & (6) & (7) \\
\hline & \multicolumn{3}{|c|}{ Full Sample } & AFR & ECA & LAC & RoW \\
\hline & -0.042 & -0.134 & 0.000 & -0.252 & $-0.302^{*}$ & -0.074 & -0.067 \\
\hline & $(0.124)$ & $(0.104)$ & $(0.063)$ & $(0.372)$ & $(0.167)$ & $(0.108)$ & $(0.193)$ \\
\hline Enterprise Surveys Corruption Measure & $0.278^{* * *}$ & $0.271^{* * *}$ & $0.214^{* *}$ & 0.098 & $0.362^{* * *}$ & $0.186^{*}$ & $0.469^{* *}$ \\
\hline Minus National Average & $(0.083)$ & $(0.061)$ & $(0.093)$ & $(0.135)$ & $(0.087)$ & $(0.106)$ & $(0.198)$ \\
\hline Natural Log of Average Total Cost & 0.003 & 0.007 & & 0.007 & $0.016^{*}$ & 0.012 & 0.007 \\
\hline of Labour & $(0.006)$ & $(0.004)$ & & $(0.012)$ & $(0.008)$ & $(0.008)$ & $(0.013)$ \\
\hline \multirow[t]{2}{*}{ Average $\%$ of Sales That Are National } & $0.003^{* * *}$ & 0.000 & & 0.002 & 0.001 & -0.001 & -0.000 \\
\hline & $(0.001)$ & $(0.001)$ & & $(0.003)$ & $(0.001)$ & $(0.001)$ & $(0.001)$ \\
\hline Country Fixed Effects & NO & NO & YES & NO & NO & NO & NO \\
\hline Dependent Variable in Deviation from National Average & NO & YES & YES & YES & YES & YES & YES \\
\hline $\mathrm{R}^{2}$ & 0.06 & 0.09 & 0.05 & 0.02 & 0.20 & 0.10 & 0.31 \\
\hline$N$ & 437 & 437 & 438 & 118 & 157 & 114 & 48 \\
\hline \multicolumn{8}{|c|}{ Panel B: Electricity Infrastructure } \\
\hline \multirow{4}{*}{ Constant } & (1) & $(2)$ & (3) & (4) & $(5)$ & (6) & (7) \\
\hline & \multicolumn{3}{|c|}{ Full Sample } & AFR & ECA & LAC & RoW \\
\hline & $0.527^{* * *}$ & -0.019 & -0.000 & -0.229 & -0.212 & 0.184 & 0.119 \\
\hline & $(0.201)$ & $(0.099)$ & $(0.096)$ & $(0.314)$ & $(0.179)$ & $(0.145)$ & $(0.223)$ \\
\hline Enterprise Surveys Corruption Measure & $0.284^{* * *}$ & $0.264^{* * *}$ & $0.228^{* *}$ & -0.026 & 0.145 & $0.697^{* * *}$ & $0.602^{* * *}$ \\
\hline Minus National Average & $(0.107)$ & $(0.074)$ & $(0.090)$ & $(0.112)$ & $(0.120)$ & $(0.124)$ & $(0.166)$ \\
\hline Natural Log of Average Total Cost & $-0.032^{* * *}$ & 0.004 & & 0.004 & $0.016^{* *}$ & -0.002 & -0.006 \\
\hline of Labour & $(0.008)$ & $(0.005)$ & & $(0.010)$ & $(0.008)$ & $(0.009)$ & $(0.014)$ \\
\hline \multirow[t]{2}{*}{ Average $\%$ of Sales That Are National } & $0.003^{*}$ & -0.000 & & 0.002 & 0.000 & -0.002 & -0.001 \\
\hline & $(0.002)$ & $(0.001)$ & & $(0.003)$ & $(0.001)$ & $(0.002)$ & $(0.001)$ \\
\hline Country Fixed Effects & NO & NO & YES & NO & NO & NO & NO \\
\hline Dependent Variable in Deviation from National Average & NO & YES & YES & YES & YES & YES & YES \\
\hline $\mathrm{R}^{2}$ & 0.10 & 0.07 & 0.05 & 0.01 & 0.06 & 0.39 & 0.30 \\
\hline$N$ & 437 & 437 & 438 & 118 & 157 & 114 & 48 \\
\hline \multicolumn{8}{|c|}{ Panel C: Telecommunications Infrastructure } \\
\hline \multirow{4}{*}{ Constant } & (1) & (2) & (3) & (4) & (5) & (6) & (7) \\
\hline & \multicolumn{3}{|c|}{ Full Sample } & AFR & ECA & LAC & RoW \\
\hline & -0.092 & -0.092 & -0.000 & 0.155 & -0.118 & -0.065 & 0.484 \\
\hline & $(0.186)$ & $(0.128)$ & $(0.046)$ & $(0.276)$ & $(0.206)$ & $(0.162)$ & $(0.450)$ \\
\hline Enterprise Surveys Corruption Measure & $0.288^{* * *}$ & $0.288^{* * *}$ & $0.295^{* * *}$ & 0.034 & $0.345^{* * *}$ & $0.362^{* * *}$ & $0.467^{* *}$ \\
\hline Minus National Average & $(0.091)$ & $(0.067)$ & $(0.076)$ & $(0.090)$ & $(0.125)$ & $(0.098)$ & $(0.214)$ \\
\hline Natural Log of Average Total Cost & $0.032^{* * *}$ & 0.005 & & -0.002 & $0.018^{*}$ & $0.016^{* *}$ & -0.007 \\
\hline of Labour & $(0.006)$ & $(0.004)$ & & $(0.008)$ & $(0.010)$ & $(0.008)$ & $(0.019)$ \\
\hline Average $\%$ of Sales That Are National & -0.001 & -0.002 & & -0.001 & -0.001 & -0.002 & -0.004 \\
\hline & $(0.002)$ & $(0.001)$ & & $(0.001)$ & $(0.002)$ & $(0.001)$ & $(0.003)$ \\
\hline Country Fixed Effects & NO & NO & YES & NO & NO & NO & NO \\
\hline Dependent Variable in Deviation from National Average & NO & YES & YES & YES & YES & YES & YES \\
\hline $\mathrm{R}^{2}$ & 0.12 & 0.09 & 0.07 & 0.07 & 0.12 & 0.17 & 0.23 \\
\hline$N$ & 402 & 402 & 402 & 97 & 155 & 112 & 38 \\
\hline
\end{tabular}

Notes: Robust standard errors in parentheses. ${ }^{*},{ }^{* *}$ and ${ }^{* * *}$ indicate significance at the $10 \%, 5 \%$ and $1 \%$ levels respectively. 


\section{References}

Acemoglu, Daron, Simon Johnson, and James A. Robinson (2001) 'The Colonial Origins of Comparative Development: An Empirical Investigation.' American Economic Review 91(5), 1369-1401

Agénor, P.R. (2010) 'A theory of infrastructure-led development.' Journal of Economic Dynamics and Control 34(5), 932-950

Al-Marhubi, F.A. (2000) 'Corruption and inflation.' Economics Letters 66(2), 199-202

Alesina, A., A. Devleeschauwer, W. Easterly, S. Kurlat, and R. Wacziarg (2003) 'Fractionalization.' Journal of Economic Growth 8(2), 155-194

Anderson, C.J., and Y.V. Tverdova (2003) 'Corruption, political allegiances, and attitudes toward government in contemporary democracies.' American Journal of Political Science 47(1), 91-109

Asiedu, E. (2002) 'On the determinants of foreign direct investment to developing countries: is Africa different?' World Development 30(1), 107-119

Blonigen, B.A., and M. Wang (2005) 'Inappropriate Pooling of Wealthy and Poor Countries in Empirical FDI Studies.' In Does Foreign Direct Investment Promote Development?, ed. E. Graham T. Moran and M. Blomström (Peterson Institute) pp. 221-243

Bose, N., S. Capasso, and A.P. Murshid (2008) 'Threshold effects of corruption: theory and evidence.' World Development 36(7), 1173-1191

Breen, Michael, and Robert Gillanders (2012) 'Corruption, institutions and regulation.' Economics of Governance 13(3), 263-285

Del Monte, A., and E. Papagni (2001) 'Public expenditure, corruption, and economic growth: the case of italy.' European Journal of Political Economy 17(1), 1-16

Esfahani, H.S., and M.T. Ramırez (2003) 'Institutions, infrastructure, and economic growth.' Journal of Development Economics 70(2), 443-477

Fernald, John G. (1999) 'Roads to prosperity? assessing the link between public capital and productivity.' American Economic Review 89(3), 619-638

Fredriksson, P.G., and J. Svensson (2003) 'Political instability, corruption and policy formation: the case of environmental policy.' Journal of Public Economics 87(7), 1383-1405

Gillanders, Robert (2011) 'The Mental Health Cost of Corruption: Evidence from SubSaharan Africa.' Working Papers 201126, School Of Economics, University College Dublin, November 
Gupta, S., H. Davoodi, and R. Alonso-Terme (2002) 'Does corruption affect income inequality and poverty?' Economics of Governance 3(1), 23-45

Hall, Robert E., and Charles I. Jones (1999) 'Why Do Some Countries Produce So Much More Output Per Worker Than Others?' The Quarterly Journal of Economics 114(1), 83116

Henisz, W.J. (2002) 'The institutional environment for infrastructure investment.' Industrial and corporate change $11(2), 355-389$

Kaufmann, Daniel, Aart Kraay, and Massimo Mastruzzi (2010) 'The Worldwide Governance Indicators : Methodology and Analytical Issues.' Policy Research Working Paper Series 5430, The World Bank, September

Kenny, Charles (2009) 'Measuring corruption in infrastructure: Evidence from transition and developing countries.' The Journal of Development Studies 45(3), 314-332

Mauro, P. (1995) 'Corruption and growth.' The Quarterly Journal of Economics 110(3), 681712

Parker, P.M. (1997) National Cultures of the World: A Statistical Reference Cross-Cultural Statistical Encyclopedia of the World (Greenwood Press)

Rodrik, Dani, Arvind Subramanian, and Francesco Trebbi (2004) 'Institutions Rule: The Primacy of Institutions Over Geography and Integration in Economic Development.' Journal of Economic Growth 9(2), 131-165

Staiger, Douglas, and James H. Stock (1997) 'Instrumental Variables Regression with Weak Instruments.' Econometrica 65(3), 557-586

Tanzi, V., and H. Davoodi (1997) 'Corruption, public investment, and growth.' IMF Working Paper WP/97/139

Transparency International (various years) 'Corruption Perceptions Index'

Treisman, D. (2007) 'What have we learned about the causes of corruption from ten years of cross-national empirical research?' Annu. Rev. Polit. Sci. 10, 211-244

Wallsten, S.J. (2001) 'An econometric analysis of telecom competition, privatization, and regulation in africa and latin america.' The Journal of Industrial Economics 49(1), 1-19

Wang, L. (2003) 'Determinants of child mortality in ldcs: empirical findings from demographic and health surveys.' Health policy 65(3), 277-299

Wei, S.J. (2000) 'How taxing is corruption on international investors?' Review of Economics and Statistics 82(1), 1-11 